\title{
An African theory of good leadership
}

\section{Author:}

Distinguished Prof

Thaddeus Metz ${ }^{1}$

\section{Affiliation:}

${ }^{1}$ University of Johannesburg, South

Africa

E-mail:

tmetz@uj.ac.za

DOI:

10.15249/12-2-204

\section{Keywords:}

African ethics; communion; decision making; employee relations; leadership; stakeholder theory; ubuntu

\section{Abstract}

This article draws on the indigenous African intellectual tradition to ground a moral-philosophical theory of leadership that is intended to rival accounts prominent in the East Asian and Western traditions. After providing an interpretation of the characteristically sub-Saharan value of communion, the article advances a philosophical account of a good leader as one who creates, sustains and enriches communal relationships and enables others to do so. The article then applies this account to a variety of topics, including what the final end of an organisation should be, how decisions ought to be made within it, who counts as a stakeholder and how to deal with non-performing or misbehaving employees. For each topic, the article notes respects in which Afro-communal leadership supports approaches that differ from those prescribed by other, more internationally familiar philosophies such as Confucianism and Kantian contract theory, and it suggests that its implications are prima facie attractive relative to them.

\section{Introduction}

International academic reflection on good leadership has tended to follow the rise of political or economic power, first in the West and then in the East. However, there is little reason to believe that the presence of power correlates strongly with moral-philosophical plausibility. Indeed, from the characteristically African perspective this article advances, the failure by some societies to have shared political and economic power is a prima facie indication that something is mistaken with their underlying value systems. 
It has been pointed out that ideas indigenous to Africa are under-represented in the English-speaking literature on leadership (Blunt \& Jones, 1997; Ncube, 2010:77-78; Nkomo, 2011:371). As the authors of a book devoted to personal growth suggest, "Of all the gifts that Africa has given the world, African values in leadership have not yet claimed the place that they could" (Nussbaum, Palsule \& Mkhize, 2010:5). There are a number of reasons for thinking that this ignorance of African ${ }^{1}$ understandings of good leadership is unwelcome. Two familiar rationales are that it is immoral, because disrespectful, to disregard an entire culture's philosophy, and that interaction in a globalised world requires familiarity with the views of "the other" as a matter of prudence. A third important rationale, however, is epistemic: any long-standing culture probably has some insight into the human condition, such that one risks being mistaken about what counts as a good leader if one remains unfamiliar with African culture. Despite having been a largely oral tradition until recently, African philosophy and related ideas have been in existence for at least several hundred years and, as this article is meant to show, their implications for leadership merit global consideration.

This article draws on the indigenous African intellectual tradition to ground a moralphilosophical theory of leadership that is meant to constitute a plausible rival to salient accounts of leadership in the East Asian and Western traditions. Specifically, it articulates an interpretation of the characteristically African value of communion, and indicates how this Afro-communal value system grounds a certain ideal approach to leadership. Along the way, the article contrasts the implications of Afro-communal leadership particularly with those of Confucianism and Kantian contract theory, and suggests that the African theory deserves to be treated as a viable alternative to them. The article focuses on business leadership in the first instance, but the points made should be applicable to a wide array of organisations.

Note that, unlike much of literature on African leadership, this article is largely prescriptive, and only minimally descriptive. It is not principally concerned to provide empirical information about the ways that African peoples have approached leadership over the centuries (Masango, 2002), that some Africans currently lead (Jackson, 2004; Newenham-Kahindi, 2009; Kuada, 2010), or that contemporary Africans tend to understand leadership (Bolden \& Kirk, 2009).

In addition, this article does not appeal to all prescriptive ideas about African leadership in the contemporary literature or from traditional practices. So, for example, it disregards the normative suggestions that African leaders should "uphold the sacredness of leadership as the main connection between people and the Creator" (Rukuni, 2009:51; see also Ndlovu, 2016) or that "group rights are always more important than individual rights" (Rukuni, 2009:107; see also Nkondo, 2007:90-91; Ncube, 2010:81). It also rejects the idea that, in order to impart unity to people at the political level, a one-party state is justified (as per Nkrumah, 1970:100-101; Rukuni, 2009:154). For yet another example, it abjures gendered conceptions of leadership that have been present in some traditional settings (see e.g. Nicholson, 2005), but also does not focus on what African values might progressively entail for women's issues (on which see Ndlovu, 2016). 
Instead of trying to accommodate every idea from the African context, this article advances a reading of one purportedly basic value from it that should be taken seriously by a 21st-century, open-minded philosopher, ethicist or related enquirer from any part of the world, and then considers what it entails for good leadership. Such an ethical orientation, as is spelled out in the next section (sec.2), is secular, relational and egalitarian. After spelling out this communal ethic, this article draws out of it a conception of good leadership (sec.3), and then applies this conception to a variety of topics, including what the final end of an organisation should be, how decisions ought to be made within it, who counts as a stakeholder and how to deal with non-performing or misbehaving employees (sec. 4). For each topic, the article notes respects in which Afrocommunal leadership supports approaches that differ from those prescribed by other, more internationally familiar views of it, and it suggests that its implications are prima facie attractive relative to them. ${ }^{2}$ The article concludes by suggesting some additional topics that merit investigation (sec. 5).

\section{Communion as a basic African value ${ }^{3}$}

In recent years, there have been a number of literate, philosophical interpretations of the African ethical tradition. Although there has of course been moral philosophy amongst the black peoples indigenous to the sub-Saharan region for several centuries, it was only with the demise of colonialism and the rise of literacy that intricate written works have appeared. For example, Kwame Gyekye $(1997,2010)$ has argued that an attractive African ethic at bottom prescribes advancing the common good, whereas Bénézet Bujo (1997) and Laurenti Magesa (1997) have contended that it requires fostering an imperceptible ("spiritual") vital energy in oneself and one's society.

By these accounts, the communitarianism that is well-known for being salient in subSaharan moral thought is of merely instrumental value; communal relationship is solely a means to promoting well-being or life-force. In contrast, according to the interpretation of sub-Saharan morality favoured here, relationality is, roughly, an end in itself. This article cannot show that this latter approach is preferable to its rivals; it is advanced as merely one plausible philosophical interpretation of sub-Saharan mores.

This article spells out an Afro-communal ethic in the context of maxims widely taken to capture indigenous or traditional sub-Saharan morality, namely, "I am because we are" and "A person is a person through other persons." Although these phrases are sometimes used to express a metaphysical claim (viz. that one could not have become who one is without living in a certain society), they are also routinely meant to express an ethical one. In particular, they are often prescriptions to become a real self or a complete person (e.g. Wiredu, 1992; Menkiti, 2004), or, in the influential southern African vernacular, they are exhortations to exhibit ubuntu, the Nguni term for humanness or human excellence (e.g. Mokgoro, 1998; Tutu, 1999:32-35).

Such an ethic is a eudaemonist or self-realisation perspective, similar to the foundations of Aristotelianism and Confucianism. The ultimate answer to the question of why one 
should live one way rather than another is the fact that it would make one a better person. There is a distinctively human and higher part of our nature, and a lower, animal self, and both can be realised to various degrees. That is, the thought is that one can be more or less of a human, person or self, and one's basic aim in life should be to develop one's humanness, personhood or selfhood as much as one can. Indeed, it is common for those from indigenous African cultures to describe those who are wicked as "not persons," "zero-persons" or even "animals" (Wiredu, 1992:199-200; Gyekye, 1997:49-51; Nkulu-N'Sengha, 2009:144). These ascriptions are meant to signify a lack of virtue, but not a lack of dignity or full moral status.

Turning to the second part of the maxims, one becomes a real self "because we are" or a complete person "through other persons", which roughly mean insofar as one prizes communal or harmonious relationships with others. As Augustine Shutte, who has provided a book-length interpretation of an ubuntu ethic, remarks, "Our deepest moral obligation is to become more fully human. And this means entering more and more deeply into community with others. So although the goal is personal fulfilment, selfishness is excluded" (2001:30). It is common for ethicists working in the African tradition to maintain, or at least to suggest, that the only comprehensive respect in which one can exhibit human excellence is by relating to others communally or harmoniously.

To begin to appreciate how one large swathe of African moral thought has been fundamentally relational, consider these remarks about sub-Saharan values and norms from theorists who are from places as diverse as South Africa, Zimbabwe, Uganda and Kenya:

[I]n African societies, immorality is the word or deed which undermines fellowship.

(Kasenene, 1998:21)

Social harmony is for us (Africans - ed.) the summum bonum - the greatest good. Anything that subverts or undermines this sought-after good is to be avoided like the plague.

(Tutu, 1999:35)

[O]ne should always live and behave in a way that maximises harmonious existence at present as well as in the future.

(Murove, 2007:181)

A life of cohesion, or positive integration with others, becomes a goal, one that people design modalities for achieving. Let us call this goal communalism, or, as other people have called it, communitarianism. In light of this goal, the virtues ... also become desirable.

(Masolo, 2010:240)

Talk of "fellowship," "harmony" and "cohesion" is recurrent in the above quotations, which suggest that these are to be valued for their own sake. That approach differs from the idea that these ways of relating are valuable merely as a means to some other value, such as the common good or vital force. It also is prima facie distinct from the most salient philosophical approaches to morally right action in the contemporary West, which appeal at bottom to utility promotion, respect for autonomy, agreement in a social contract or God's will. ${ }^{5}$ 
The next question is how one is to understand these relational goods, or what this article most often refers to as "communion". Representative African theorists are again quoted about what it means to live in communion, harmony, etc. with others, after which the article draws on their comments to advance a principle to guide thought about leadership matters, particularly but not solely as they concern a business:

Every member is expected to consider him/herself an integral part of the whole and to play an appropriate role towards achieving the good of all.

(Gbadegesin, 1991:65)

$[\mathrm{H}]$ armony is achieved through close and sympathetic social relations within the group.

(Mokgoro, 1998:17)

The fundamental meaning of community is the sharing of an overall way of life, inspired by the notion of the common good.

(Gyekye, 2004:16)

[T]he purpose of our life is community-service and community-belongingness.

(Iroegbu, 2005:442)

If you asked $u$ buntu advocates and philosophers: What principles inform and organise your life? ... the answers would express commitment to the good of the community in which their identities were formed, and a need to experience their lives as bound up in that of their community.

(Nkondo, 2007:91)

What is striking about these characterisations of how to commune, harmonise or otherwise become a real person is that two distinct relational goods are repeatedly mentioned, namely, considering oneself part of the whole, being close, sharing a way of life, belonging and experiencing oneself as bound up with others, on the one hand, and then achieving the good of all, being sympathetic, acting for the common good, serving the community and being committed to the good of one's society, on the other.

These two facets of a communal relationship have been distinguished and reconstructed with some precision (Metz, 2013, 2017a). It is revealing to understand the relationship of "identifying" with others or "sharing a way of life" with them (i.e. being close, belonging, etc.) to be the combination of exhibiting certain psychological attitudes of cohesion and cooperative behaviour consequent to them. The attitudes include a tendency to think of oneself as a member of a group with the other and to refer to oneself as a "we" (rather than an "I"), a disposition to feel pride or shame in what the other or one's group does and, at a higher level of intensity, an emotional appreciation of the other's nature and value. The cooperative behaviours include being transparent about the terms of interaction, allowing others to make voluntary choices, acting on the basis of trust, adopting compatible goals and, at the extreme end, choosing for the reason that "this is who we are".

What is labelled the relationship of "exhibiting solidarity" with or "caring" for others (i.e. acting for others' good, etc.) is similarly aptly construed as the combination of exhibiting certain psychological attitudes and engaging in helpful behaviour. Here, the attitudes are ones positively oriented towards the other's good, and they include an 
empathetic awareness of the other's condition and a sympathetic emotional reaction to this awareness. The actions are not merely those likely to be beneficial, that is, to meet her biological, psychological and social needs, but also ones done consequent to certain motives, say, for the sake of making the other better off or even a better person.

Bringing things together, here are some concrete and explicit principled interpretations of "I am because we are" and "A person is a person through other persons": one should strive to become a real self, which is matter of prizing those capable of identity and solidarity. Or, one ought to develop personhood, which means honouring people by virtue of their dignified ability to be party to communal relationships of sharing a way of life and caring for others' quality of life.

Conversely, one lacking in human excellence, or who is "not a person", would be one who fails to respect those able to commune. Substantial vice or wrongdoing by this ethic consists of prizing the opposite, discordant relationships of acting on an "us versus them" attitude, subordinating others, harming them and doing so out of indifference to their good.

This philosophical specification of a communal ethic appears to capture well the moral value of many salient traditional practices south of the Sahara desert. In brief, recurrent themes of consensus-seeking in the realm of politics, collective harvesting when it comes to production and reconciliation in the sphere of criminal justice are all plausibly viewed as ways of prizing communion or honouring people by virtue of their communal nature. ${ }^{6}$ To "honour" or "prize" communion, or those capable of it, is a deontological notion, and so is to be contrasted with a consequentialist prescription to promote communion as much as one can, and wherever one can, in the long run. So, for example, one should give some priority to the communal relationships of which one is already a part, instead of cutting them off if doing so would foster marginally more communion on the part of others. Ceteris paribus, the stronger and longer one's communal ties with others, the greater the obligation to help them. This interpretation of partiality is meant to reconstruct the traditional practice of prioritising aid to blood relatives (on which see Appiah, 1998).

However, partiality is not meant to be absolute, and the urgent needs of strangers, who also matter for their own sake by virtue of being capable of communion, merit consideration and must be weighed up against the interests of intimates. The impartial idea that every person has dignity is also prominent in the African tradition (Wiredu, 1992:199-200; Gyekye, 2010:sec. 6), and is expressed here in terms of the natural ability to be communed with and to commune.

In addition, honouring communion means that one normally should not seek to realise it by means of substantial discord, at least when it is directed towards innocent parties. This restriction on how to promote communion is a way to accommodate human rights, which more or less protect innocent individuals from being egregiously used merely as a means to a greater (perceived) good. The Afro-communal principle therefore is not consequentialist in the sense of implying that the means by which one maximises a state of affairs lacks moral significance in itself. 
There is much more that could be said to spell out and to motivate this Afro-communal ethic. For example, the question of which others to commune with could use more discussion. Do they include imperceptible persons such as ancestors, or perhaps some non-persons such as animals? These are important issues, but they do not need to be addressed here, in order to draw some reasonably firm conclusions about what counts as good leadership in relation to human persons. It is enough to note that a moral agent at least must respect human beings capable of communion, where those with whom she has already communed are entitled to some priority relative to strangers, whose needs nonetheless matter by virtue of being potential sites of communion.

\section{From an Afro-communal ethic to an account of leadership}

The rest of this article works to apply the ethic from the previous section to an array of issues pertaining to good leadership. This section provides an abstract characterisation of how to lead in terms of the Afro-communal ethic, while the following section applies it to several concrete matters, such as how to make decisions in a firm and whom to treat as a stakeholder.

In the light of the previous section's analysis, one can now grasp the import of maxims about leadership from the literature that might otherwise have been opaque. For example, probably the most common saying in an African context about good leadership is, "A king is a king through his people" (e.g. Pheko \& Linchwe, 2008:399, 409; Mofuoa, 2015:32). There is also this remark: "Leaders have a deep awareness that they are what they are because of other people" (Nussbaum, Palsule \& Mkhize, 2010:10). Notice how these maxims echo the ones about personhood ("A person is a person through other persons") and selfhood ("I am because we are") from the previous section. Supposing the communal interpretation of ethical behaviour in general made there is plausible, it would make sense to construe these statements about leadership this way: one should become a real leader, which one can do insofar as one relates communally and enables others to commune.

This conception is an instance of servant leadership, which phrase abounds in the literature on African approaches to leadership (Mbigi \& Maree, 2005:102; Nicholson, 2005:260-261; Bhengu, 2006:185-187, 229; Khoza, 2006:58-59; Mbigi, 2007:298-301; Msila, 2014; Ndlovu, 2016; Ndlovu-Gatsheni \& Ngcaweni, 2017). Broadly speaking, a servant leader is not so much one who gets others to do what he wants or thinks best, but is roughly one who does much to help others. Servant leadership is of course not unfamiliar in the Western literature (e.g. Greenleaf, 2002). However, unlike in the Western literature on leadership, servant leadership is the patently predominant theme in the African literature on it. In addition, the Afro-communal ethic grounds a distinct specification of precisely what should be involved in helping others: a good leader is one who helps to meet others' needs, and above all their need to realise their social nature by prizing communal relationship. 
By this approach, communion is a way of relating to be pursued as an end, not merely as a means to other values such as, say, productivity or innovation (which is what is emphasised, at times, in Mbigi \& Maree, 2005:viii, 2, 65, 114, 117; Bhengu, 2006:155, 157, 169-170). The Afro-communal ethic should not be read as entailing the banalities that social capital or effective teamwork are useful to succeed in a competitive environment. Instead, it supports the bolder claim that a good leader seeks out a certain way of relating for its own sake.

\section{Implications of Afro-communal leadership}

What would a firm or other large organisation look like if it were guided by the Afrocommunal conception of good leadership? For example, what would the firm strive to achieve, how would decisions be made within it and whom would it consider to be stakeholders? This section answers these kinds of questions, often drawing contrasts with typical East Asian and Western conceptions of good leadership.

\subsection{What is the point of a firm?}

Prizing communion differs from goal-pursuit, as per Kantianism, or desire-satisfaction, as per utilitarianism, which are characteristically Western and individualist views of what a firm, or other organisation with a large public influence, ultimately ought to be striving to achieve. Instead of the point of a firm being to satisfy contingent and variable demand, a firm lead by Afro-communal values would exhibit solidarity with consumers, meaning that it would do what is expected to enable them to live objectively better lives, particularly socio-moral ones.

This orientation towards people's needs, and especially their virtue, means that there would be reflection amongst at least shareholders and managers on whether a firm is selling something that is, if not in fact good for people, then at least likely to be (cf. Lutz, 2009). If an Afro-communal leader took over a firm that sold cigarettes or food with trans fats, she would make a concerted effort to shift production towards something that, for all we can tell, would not cause addiction, inflict serious bodily harm and, as a consequence of these, disrupt familial and friendly relationships. Consumers might freely choose bad things, but that is not a sufficient reason to sell them for one who deems good leadership to consist of prizing communion.

Confucian values, so prominent in East Asia, are also well known for similarly directing a firm to act in an objectively beneficent way towards consumers (e.g. Ip, 2009). In addition, Confucianism is characteristically relational, as opposed to individualist, and so again is similar to the Afro-communal ethic. However, one difference with the Afro-communal approach, in terms of what the final end of a firm should be, is that Confucianism tends to prize relationship as a final value to be promoted that can be distinct from the good of individuals. ${ }^{7}$ If relationships such as balance or integration have some significant final value in themselves, then a leader could wind up treating individuals merely as 
a means to the end of promoting them, something admitted by those sympathetic to Confucianism (e.g. Ip, 2009:470; and Li, 2014:14). In contrast, by the Afro-communal conception of leadership, each person has a dignity in virtue of her capacity to commune and to be communed with, which means that, to treat every person with respect, a leader must strive to meet the needs of each.

\subsection{Whom should a firm aid?}

A firm cannot meet the needs of literally all; it must rather attend to those of its stakeholders. But who counts as a stakeholder, that is, as someone for whom a firm has moral reason to go out of its way to aid?

In the Western tradition, there are two main moral reasons to help someone: she is amongst the worst off and so owed aid because of a general duty to help, or she is someone whom we have assumed an obligation to aid in particular, say, by promising or by accepting the benefits from a cooperative scheme of which she is a member. By this largely Kantian and Rawlsian approach, the leader of a firm roughly must take positive steps to carry out what it has contracted to do and must also donate, in the form of a corporate social responsibility (CSR) programme, to those who are especially badly off.

In addition to these two moral reasons to aid others, the Afro-communal ethic grounds a third reason: one has already related communally with others (Metz, 2017b; Woermann \& Engelbrecht, 2017). If one has been party to a communal relationship with others intensely or for a long time, and especially both, then one can have some strong moral reason to aid these intimates as opposed to strangers, even if the latter are worse off and if one did not promise to aid the former.

Consider one's reason to aid one's children. It is not that they are amongst the worst off or are badly off at all, at least for most readers of this article. It is also not that one promised to do so; few of us have ever made an agreement to continue to look after our children as opposed to aiding other people's children. Or, more deeply, if we did make such a promise, we plausibly would have been obligated to aid our own children even if we had not. The natural explanation of the duty to aid one's own children is that one has exhibited identity and solidarity with them in substantial ways and over a long period of time. To the extent that one's relationships with friends, co-workers and neighbours are similar in nature and extent to one's relationships with one's children (even if less intense and shorter in duration), one also has unassumed duties of some weight to aid them as opposed to others. Communion encumbers.

Applied to a business context, Afro-communal leadership would mean that a firm goes out of its way to help not merely those in desperate need of aid or those it has promised to aid, but also those with whom it has shared a way of life in some respect, including its society. ${ }^{8}$ African thinkers have sometimes noted the duty of a firm to aid society (Bhengu, 2006:160-161; Amaeshi \& Idemudia, 2015), but the appeal to Afro-communal leadership explains why the duty obtains: a firm has at least identified with the society in which it is based and therefore has moral reason to exhibit solidarity with it, too. 
An additional implication is that if a firm has a long-standing relationship with a particular supplier, the former's leaders would have some moral reason to continue to contract with the latter, even if a new supplier would be marginally less expensive. The reason is merely pro tanto and not invariably conclusive, i.e. a firm's leaders need not continue to contract with a supplier regardless of how expensive its goods or how shoddy its services become. The point is that there would usually be some moral cost to dumping a long-standing supplier. Furthermore, in those cases in which there would be little or no moral cost to breaking ties with such a stakeholder, a likely explanation would be that this supplier has itself failed to live up to its respective obligation to commune and has instead become exploitive or neglectful.

Running with this dimension of partiality in African ethics, two scholars have recently suggested that, when it is applied to the context of business ethics, the word "stakeholders" should be replaced with "relationholders" (Woermann \& Engelbrecht, 2017). For them, stakeholder-talk is "contaminated" by the idea that "different parties'

interests are dependent on the power and influence that these parties can exert on the organisation due to the strength of the contractual underpinnings of their claims or stakes" (Woermann \& Engelbrecht, 2017). In contrast, the word "relationholder" highlights the idea that sometimes a firm can have some moral reason to aid particular individuals beyond contractual terms with them or any voluntary assumption of an obligation to aid them. Prior relationship can be sufficient to provide reason of some weight to continue or even strengthen it.

\subsection{How should a firm make decisions?}

An account of which decisions a firm should make (say, when it comes to which final ends to pursue or whom to count as being owed aid) is one thing, while an account of how to make those decisions is another. How should business and other leaders arrive at a determination of which policies and practices to adopt?

Here, the Afro-communal theory parts ways with much of both the East Asian and Western traditions of philosophical thought about leadership. Typical Western thinkers and managers, appealing to Kantian (or Lockean) ideas, consider consent to be ruled to be sufficient to give managers the authority to determine the course of a firm. Basically, the fact that a worker has contracted to submit her labour-power to the direction of a firm's managers in exchange for a wage is enough to warrant her obedience to managerial decree. East Asian thinkers and managers, appealing particularly to Confucianism, consider superior qualifications sufficient to give managers the authority to govern the workplace (e.g. Ip, 2009:469-470). Both traditions can of course recommend consultation with employees as often being a useful way to further the proper final ends of a firm. However, neither approach entails that input, let alone authorisation, from employees is morally required as a way to give them their due.

Afro-communal leadership, in contrast, does. Perhaps the most salient theme in the literature on good leadership in the sub-Saharan tradition is the idea that leaders 
should normally deploy consensual democracy when making decisions (Bhengu, 1996, 2006:191-193, 230; Nussbaum, 2003; Mbigi \& Maree, 2005:8, 29-30, 58-60; Khoza, 2006; Boon, 2007:82-93, 103-109, 125, 150-152; Mbigi, 2007:299-300; Louw, 2010; Ncube, 2010:79-80). By this approach, it is not enough to consult with employees or even to give them a vote; in addition, all in the firm should usually be expected to agree to the essentials before going forward. Agreeing does not imply that everyone comes to share the same judgement, but instead means, at the core, that no one has objections to the proposal so strenuous as to hold back the rest from acting on it.

Such an approach seems to follow directly from the Afro-communal ethic expounded above. If a key goal is to realise communion in a firm or other organisation, then a leader will aim to ensure that all genuinely share a way of life, which includes sharing the power to create it together. Sharing a way of life, as explained above, is not merely people living the same way, which way of life could be imposed from above. Instead, it essentially includes cooperative participation, prescribing unanimitarian democracy when feasible, not merely when it comes to (representative) political legislation, but also other major public spheres of life.

Two additional facets of communion would be reliably fostered by consensual democracy. Such an approach to decision making would best enable people to enjoy a sense of togetherness, thinking of themselves as a "we" and taking pride in their collective accomplishments. And, then, consensual democracy would usually be expected to realise solidarity (on which see Gyekye, 1997:130-131, 142). Everyone's interests are most likely to be promoted when everyone freely signs onto a policy consequent to deliberation about it.

\subsection{How should a workplace be organised?}

In the 21st century efficiency is invariably sought by means of managerialism, in both the East and the West. That is, in order to maximise outputs and minimise inputs, subordinates are steered, usually with money or power, in ways that call for the production of standardised outputs according to measurable criteria. Such an approach is thought to be justified philosophically either by the idea that managerialist production would benefit society or that it has been freely agreed to by workers. Afro-communal leadership, however, is ambivalent about the aptness of such a mode of production.

On the one hand, a firm has moral reason to commune with shareholders and with consumers, which provides some reason for it to "squeeze" employees to do what it takes to produce goods/services efficiently. If managerialism best fostered efficiency of a sort that was likely to make the lives of shareholders and consumers objectively better off, that would be some reason for a leader to use it to orient the workplace.

On the other hand, managerialism is on the face of it "anti-social" when it comes to the way that managers treat employees (as per Metz, 2017c). It hardly fosters a sense of togetherness between these two groups of people. Its use of steering mechanisms, such as financial incentives and punitive threats, is prima facie incompatible with cooperative 
participation on the part of workers. Although workers might gain financially from doing well by managerialist criteria, their own good in the production process is of little interest beyond avoiding health and safety violations. Finally, managerialism is unlikely to foster sympathy, and probably encourages managers to view workers as human resources, not so much as people whose interests matter for their own sake.

In addition, managerialism plausibly alienates workers from each other, too, not just from managers. If workers are competing against each other for scarce rewards, as is often the case, then a spirit of camaraderie amongst them and an inclination of some to sacrifice for the sake of others are discouraged.

It appears, therefore, that the value of communion pulls in different directions when it comes to how to organise a workplace. As two scholars have recently noted (Woermann \& Engelbrecht, 2017), by an African ethic that prizes communal relationship, employees are particularly important stakeholders (or "relationholders"). Typically the relationship between them and the firm is especially intimate and long-standing, meaning that the firm owes them quite a lot, and that their needs are not invariably to be sacrificed for the sake of the interests of shareholders and consumers. Even so, there are some clear and substantial benefits from managerialism, at least in terms of making money and satisfying demand - which could be ways of meeting needs.

The natural resolution of the tension is compromise. Here are two examples of how a leader inspired by Afro-communal values might proceed.

First, he might retain the use of numerical targets that workers must meet, but not set them down unilaterally. Instead, he could go beyond merely consulting with workers about targets by obtaining their unanimous agreement to them, upon discussion of what would be best for all those affected by the firm.

Second, a leader might retain the use of a year-end bonus to express appreciation and to motivate, but not allocate it strictly in proportion to the quantified output of individuals. Instead, he could award the same bonus to all those who have done well enough, if not share profits in a more robust sense with them (briefly suggested by Bhengu, 2006:179-180, 192; and Ncube, 2010:79).

\subsection{How are emotions of relevance to an organisation?}

Any plausible view of leadership will entail that a leader is good insofar as she takes employees' emotions into account. However, what stands out about the Afro-communal approach to leadership is that cultivating certain feelings and attitudes is good for its own sake, not merely as a means to an end in order to motivate employees to perform, the natural approach of Confucianism and Kantian contract theory.

A communal relationship is not merely behavioural, that is, not merely a matter of coordination and mutual aid. In addition, it is, in part, essentially psychological and specifically emotional. For one, part of a communal relationship involves a sense of 
togetherness such as feeling pride in what others accomplish and liking being with others. For another, communion includes feeling sympathy and compassion for others.

Insofar as one major task of a leader is to forge communion in a firm, she must therefore be committed to prompting such feelings and attitudes, and do so as ends in themselves. Such a theoretical rationale explains why some African leadership proponents have been right to recommend - fascinatingly - that an organisation include ritual, prayer, song and dance (Mbigi \& Maree, 2005:50-52, 102, 108; Bhengu, 2006:186-187; Boon, 2007:68, 83; Rukuni, 2009:119-120). These would be ways to bring people closer together on an emotional level and thereby to realise communion along a certain dimension.

\subsection{How should conflict be resolved?}

Consider two ways of dealing with actual and potential problems in the workplace that Afro-communal leadership would abjure. First, note that American managers are known for having the discretion to fire at will for under-performance or misbehaviour. At the end of the 20th century, more than two-thirds of American workers could be dismissed immediately for failing to perform (or even for no cause at all, on which see Hiley, 1985:1), an approach that is on the face of it consistent with a contractual ethical orientation.

Second, think about the reputation that Chinese managers in Africa have for hiring Chinese labourers, and not so much African ones, because the former are expected to be more highly skilled and compliant than the latter. Although it appears that such practices are in fact not so widespread (on which see Sautman \& Hairong, 2015; and Xiaoyang, 2016), it is worth considering what would be wrong with them from an Afrocommunal perspective.

There is an underlying similarity between immediately dismissing someone perceived to be a problem in the workplace and not even hiring those expected to be: exclusion. In contrast, inclusion is a salient theme in the literature on African leadership. It highlights using emotional intelligence to address conflict, trying hard to develop weak employees and enabling everyone to feel part of a community (Blunt \& Jones, 1997:15; Nicholson, 2005:261; Boon, 2007:62-63; Msila, 2014:1107). Conspicuously absent from African thought about leadership are ideas of using fear, imposing retribution or simply removing an employee altogether (without having tried to bring him up to speed).

Again, a focus on communion provides a plausible theoretical explanation of why inclusiveness should be the overarching approach of a good leader. If what matters morally about us is our capacity to commune and to be communed with, then respect for that special value will mean creating relationships and repairing them when they have broken down. Instead of summarily dismissing an employee who has made a mistake, a good leader would try to ascertain why she did so, consider whether the employee could be reformed and, if so, offer a second chance. And instead of avoiding hiring people who might be more difficult to work with as employees, a good leader would give them a chance and do what he could to develop their abilities, particularly if he were a visitor in their land. 
For one inspiring vision of what inclusiveness can mean, consider the tale of a 19th century southern African military leader who, upon having successfully repelled an attack, sent the losing party cattle as a present (Mofuoa, 2015:28, 32; Prozesky, 2015:10). There is something dignified here, which would be missing if the leader had instead sought to make an example of the defeated warriors, imposed retribution on them for their wrongful attack, or even simply left them to fend for themselves in disarray. A compelling question is how such an attitude might be displayed in a business context.

\section{Conclusion: some additional issues}

It is not obvious what makes someone a good leader, particularly in the light of conflicting value systems around the world. This article has expounded a conception of good leadership that is under-appreciated in the English-speaking literature on the topic. Specifically, it has drawn on the African intellectual tradition to develop a normative theory of leadership in terms of prizing people by virtue of their capacity to relate communally. Although some of its concrete prescriptions have already been recommended in the literature, this article has aimed to show how they can all be theoretically grounded on the basic value of communion that is prominent in African philosophical discussions of morality. It has also sought to argue that these prescriptions constitute plausible alternatives to what characteristically East Asian or Western accounts of leadership support.

Supposing the attempt to ground various dimensions of good leadership on an Afrocommunal ethic has been prima facie attractive, other matters also merit investigation. For example, is communion compatible with innovation and entrepreneurialism, which are so important not merely for business but really any organisation with a significant influence on the public? Or, are these best justified by individualist and so largely Western values? Is there a characteristically indigenous African approach to time, and, if so, is it a function of communion? Is it compatible with (enough) efficiency? Is consensual democracy to be favoured in literally every context, or is it inappropriate when it comes to dealing with, say, children in a family and soldiers during a time of war? If this article has been successful, the reader will agree that these questions merit answers in future work.

\section{Acknowledgements}

This article has benefited from oral input received at the Transcultural Leadership Summit 2017, held at the Leadership Excellence Institute Zeppelin in Germany, and written input from two anonymous referees for the African Journal of Business Ethics. A close relative of this article has appeared in J. Wieland and J. Baumann Montecinos (eds.), Transcultural Leadership: Learning about Sub-Saharan Africa (Marburg: Metropolis, 2018), 6-28, and the author would like to thank these editors for permitting it to be reprinted here. 


\section{References}

Ake, C. (1987). The African context of human rights. Africa Today, 34:5-12.

Amaeshi, K. \& Idemudia, U. (2015). Africapitalism: A management idea for business in Africa? Africa Journal of Management, 1:210-223. https://doi.org/10.1080/23322373.2015.1026229

Appiah, A. (1998). Ethical systems, African. In: E. Craig (ed.). Routledge encyclopedia of philosophy. London: Routledge.

Bhengu, M.J. (1996). Ubuntu: The essence of democracy. Cape Town: Novalis Press.

Bhengu, M.J. (2006). Ubuntu: The global philosophy for humankind. Cape Town: Lotsha Publications.

Blunt, P. \& Jones, M. (1997). Exploring the limits of western leadership theory in East Asia and Africa. Personnel Review, 26:6-23. https://doi.org/10.1108/00483489710157760

Bolden, R. \& Kirk, P. (2009). African leadership. International Journal of Cross Cultural Management, 9:69-86. https://doi.org/10.1177/1742715009337761

Boon, M. (2007). The African way: The power of interactive leadership. 3rd edition. Cape Town: Zebra Press.

Bujo, B. (1997). The ethical dimension of community: The African model and the dialogue between North and South. (Transl. C.N. Nganda). Nairobi: Paulines Publications Africa.

Chang, H-C. \& Holt, G.R. (1991). More than relationship: Chinese interaction and the principle of kuan-hsi. Communication Quarterly, 39:251-271. https://doi.org/10.1080/01463379109369802

Gbadegesin, S. (1991). African philosophy. New York: Peter Lang.

Greenleaf, R. (2002). Servant leadership. New York: Paulist Press.

Gyekye, K. (1997). Tradition and modernity: Philosophical reflections on the African experience. New York: Oxford University Press. https://doi.org/10.1093/acprof:oso/9780195112252.001.0001

Gyekye, K. (2004). Beyond cultures. Ghanaian philosophical studies, Vol. III. Washington, D.C.: Council for Research in Values and Philosophy.

Gyekye, K. (2010). African ethics. In: E. Zalta (ed.). Stanford encyclopedia of philosophy. https://plato.stanford. edu/entries/african-ethics/

Hiley, D. (1985). Employee rights and the doctrine of at will employment. Business and Professional Ethics Journal, 4:1-10. https://doi.org/10.5840/bpej19854141

Ip, P.K. (2009). Is Confucianism good for business ethics in China? Journal of Business Ethics, 88:463-476. https://doi.org/10.1007/s10551-009-0120-2

Iroegbu, P. (2005). Beginning, purpose and end of life. In: P. Iroegbu \& A. Echekwube (eds.). Kpim of morality ethics. Ibadan: Heinemann Educational Books. 440-445.

Jackson, T. (2004). Management and change in Africa. London: Routledge. https://doi.org/10.4324/9780203477069

Kasenene, P. (1998). Religious ethics in Africa. Kampala: Fountain Publishers.

Khoza, R. (2006). Let Africa lead. Johannesburg: Vezubuntu.

Kuada, J. (2010). Culture and leadership in Africa. African Journal of Economic and Management Studies, 1:9-24. https://doi.org/10.1108/20400701011028130

Li, C. (2014). The Confucian philosophy of harmony. London: Routledge.

Louw, D. (2010). Power sharing and the challenge of ubuntu ethics. Paper presented at the Forum for Religious Dialogue Symposium of the Research Institute for Theology and Religion held at the University of South Africa, 26-27 March 2009. http://uir.unisa.ac.za/handle/10500/4316

Lutz, D. (2009). African ubuntu philosophy and global management. Journal of Business Ethics, 84:313-328. https://doi.org/10.1007/s10551-009-0204-z

Magesa, L. (1997). African religion. Maryknoll, N.Y.: Orbis Books.

Masango, M. (2002). Leadership in the African context. Verbum et Ecclesia, 23:707-718. https://doi.org/10.4102/ ve.v23i3.1234

Masolo, D.A. (2010). Self and community in a changing world. Bloomington: University of Indiana Press. 
Mbigi, L. (2007). The spirit of African leadership. In: K. April \& M. Shockley (eds.). Diversity. London: Palgrave Macmillan. 294-303. https://doi.org/10.1057/9780230627529_19

Mbigi, L. \& Maree, J. (2005). Ubuntu: The spirit of African transformation management. Randburg: Knowres Publishing.

Menkiti, I. (2004). On the normative conception of a person. In: K. Wiredu (ed.). A companion to African philosophy. Malden, M.A.: Blackwell. 324-331.

Metz, T. (2013). The western ethic of care or an Afro-communitarian ethic? Finding the right relational morality. Journal of Global Ethics, 9:77-92. https://doi.org/10.1080/17449626.2012.756421

Metz, T. (2015). How the West was one: The western as individualist, the African as communitarian. Educational Philosophy and Theory, 47:1175-1184. https://doi.org/10.1080/00131857.2014.991502

Metz, T. (2016). An African theory of social justice: Relationship as the ground of rights, resources and recognition. In: C. Boisen \& M. Murray (eds.). Distributive justice debates in political and social thought. Abingdon: Routledge. 171-190.

Metz, T. (2017a). Toward an African moral theory, revised edition. In: I. Ukpokolo (ed.). Themes, issues and problems in African philosophy. London: Palgrave Macmillan. 97-119. https://doi.org/10.1007/978-3-31940796-8_7

Metz, T. (2017b). Ancillary care obligations in light of an African bioethic: From entrustment to communion. Theoretical Medicine and Bioethics, 38:111-126. https://doi.org/10.1007/s11017-017-9404-1

Metz, T. (2017c). Managerialism as anti-social: Some implications of ubuntu for knowledge production. In: M. Cross \& A. Ndofirepi (eds.). Knowledge and change in African universities, Vol. 2. Rotterdam: Sense Publishers. 139-154. https://doi.org/10.1007/978-94-6300-845-7_8

Mofuoa, K. (2015). The exemplary ethical leadership of King Moshoeshoe of Basotho of Lesotho in the nineteenth century southern Africa. Journal of Public Administration and Governance, 5:21-35. https://doi. org/10.5296/jpag.v5i3.8129

Mokgoro, Y. (1998). Ubuntu and the law in South Africa. Potchefstroom Electronic Law Journal, 1:15-26.

Msila, V. (2014). African leadership models in education. Anthropologist, 18:1105-1114. https://doi.org/10.108 0/09720073.2014.11891593

Murove, M.F. (2007). The Shona ethic of ukama with reference to the immortality of values. The Mankind Quarterly, 48:235-241.

Ncube, L. (2010). Ubuntu: A transformative leadership philosophy. Journal of Leadership Studies, 4:77-82. https://doi.org/10.1002/jls.20182

Ndlovu, P.M. (2016). Discovering the spirit of ubuntu leadership. London: Palgrave Macmillan. https://doi.org/ $10.1057 / 9781137526854$

Ndlovu-Gatsheni, S. \& Ngcaweni, B. (eds.) (2017). Nelson Rolihlahla Mandela: Decolonial ethics of liberation and servant leadership. Trenton, N.J.: Africa World Press.

Newenham-Kahindi, A. (2009). The transfer of ubuntu and indaba business models abroad. International Journal of Cross Cultural Management, 9:87-108. https://doi.org/10.1177/1470595808101157

Nicholson, N. (2005). Meeting the Maasai: Messages for management. Journal of Management Inquiry, 14:255-267. https://doi.org/10.1177/1056492605279095

Nkomo, S. (2011). A postcolonial and anti-colonial reading of "African" leadership and management in organization studies. Organization, 18:365-386. https://doi.org/10.1177/1350508411398731

Nkondo, G.M. (2007). Ubuntu as a public policy in South Africa: A conceptual framework. International Journal of African Renaissance Studies, 2:88-100. https://doi.org/10.1080/18186870701384202

Nkrumah, K. (1970). Consciencism: Philosophy and ideology for de-colonization. Revised edition. New York: Monthly Review.

Nkulu-N'Sengha, M. (2009). Bumuntu. In: M.K. Asante \& A. Mazama (eds.). Encyclopedia of African Religion. Los Angeles: Sage. 142-147. https://doi.org/10.4135/9781412964623.n100

Nussbaum, B. (2003). Ubuntu and business. World Business Academy Perspectives, 17:1-16. 
Nussbaum, B., Palsule, S. \& Mkhize, V. (2010). Personal growth, African style. Johannesburg: Penguin Books.

Pheko, B. \& Linchwe, K. (2008). Leadership from two cultural perspectives - a tune or discord: Botswana's experience. International Journal of Lifelong Education, 27:399-411. https://doi.org/10.1080/0260137080 2051397

Prozesky, M. (2016). Ethical leadership resources in southern Africa's Sesotho-speaking culture and in King Moshoeshoe I. Journal of Global Ethics, 12:6-16. https://doi.org/10.1080/17449626.2016.1146789

Rukuni, M. (2009). Leading Afrika. New York: Penguin.

Sautman, B. \& Hairong, Y. (2015). Localizing Chinese enterprises in Africa: From myths to policies. Thought Leadership Brief, 5:1-4. http://iems.ust.hk/wp-content/uploads/2015/02/HKUST_IEMS_Thought_ Leadership_Brief_Issue5.pdf

Shutte, A. (2001). Ubuntu: An ethic for the new South Africa. Cape Town: Cluster Publications.

Tutu, D. (1999). No future without forgiveness. New York: Random House.

Wiredu, K. (1992). The African concept of personhood. In: H. Flack \& E. Pellegrino (eds.). African-American perspectives on biomedical ethics. Washington, D.C.: Georgetown University Press. 104-117.

Woermann, M. \& Engelbrecht, S. (2017). The ubuntu challenge to business: From stakeholders to relationholders. Journal of Business Ethics. https://doi.org/10.1007/s10551-017-3680-6

Xiaoyang, T. (2016). Does Chinese employment benefit Africans? African Studies Quarterly, 16:107-128. 


\section{Endnotes}

1. This article uses geographical labels such as "African" and "Western" to mean features salient in a large array of space and over a long span of time (as per Metz 2015). Hence, these terms imply neither that these features can be found solely in this place, nor that they can be found everywhere in it.

2. This article focuses on contrasting the implications of Afro-communal leadership with common practices that are prescribed by familiar philosophies of leadership in East Asia and the West, not with practices in these latter locales that might be exceptions to the rule. Its aim is to advance a theory grounded on African values that entails and plausibly explains intuitively attractive facets of leadership, which is not to suggest that contexts beyond Africa are devoid of good leadership or some instances of a communal approach towards it.

3. Much of this section borrows from previously published work, particularly Metz (2016). What is intended to be new here is not the theoretical interpretation of African ideas about community, but rather their application to considerations of leadership.

4. For a survey of how several sub-Saharan peoples understand these maxims, see NkuluN'Sengha (2009).

5. For contrasts with the ethic of care, see Metz (2013).

6. For a much fuller account of the status of these practices as African, and reason to think that the communal ethic best justifies them, see Metz (2017a).

7. There are strands of African ethics that are similarly corporatist, ascribing final value to a group, and not to individuals insofar as they are capable of relating in certain ways. For one clear example, see Ake (1987).

8. Although typical Western moral theories have difficulty accounting for this sort of duty, Confucian ethics, which is relational, does so easily (see discussion of guanxi in, e.g. Chang \& Holt, 1991). 